\title{
openheart Effect of the adult pneumococcal polysaccharide vaccine on cardiovascular disease: a systematic review and meta-analysis
}

\author{
Shu Ren, ${ }^{1}$ David Newby, ${ }^{1}$ Shu Chuen Li, ${ }^{2}$ Emily Walkom, ${ }^{1}$ Peter Miller, ${ }^{1}$
} Alexis Hure, ${ }^{1,3}$ John Attia ${ }^{1,3}$

To cite: Ren S, Newby D, Li SC, et al. Effect of the adult pneumococcal polysaccharide vaccine on cardiovascular disease: a systematic review and metaanalysis. Open Heart 2015;2: e000247. doi:10.1136/ openhrt-2015-000247

- Additional material is available. To view please visit the journal (http://dx.doi.org/ 10.1136/openhrt-2015000247).

Received 24 January 2015 Revised 5 April 2015 Accepted 3 June 2015

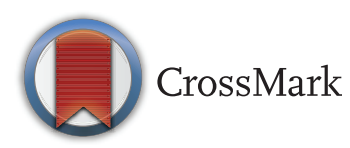

${ }^{1}$ Faculty of Health and Medicine, School of Medicine and Public Health, University of Newcastle, Newcastle, Australia

${ }^{2}$ Faculty of Health and Medicine, School of Biomedical Sciences and Pharmacy, University of Newcastle, Newcastle,

Australia

${ }^{3}$ Hunter Medical Research Institute, Newcastle, Australia

Correspondence to

Dr Shu Ren;

shu.ren@uon.edu.au

\section{ABSTRACT}

Animal models and clinical studies suggest a mechanistic link between the pneumococcal polysaccharide vaccine (PPV) and a cardiovascular protective effect. However, conflicting results exist from several large observational studies in humans. We set out to systematically review current literature and conduct meta-analyses of studies on PPV and cardiovascular outcomes. Medline, Embase and CENTRAL were searched for randomised controlled trials (RCTs) and observational studies in adults, using PPV as the intervention, up to 30 April 2014. Studies that compared PPV with a control (another vaccine, no vaccine or placebo) and recorded ischaemic events were included in this review. Two investigators extracted data independently on study design, baseline characteristics and summary outcomes. Study quality was examined using the Newcastle-Ottawa Quality Assessment Scale. Pooled estimates using random effects models and their $95 \%$ Cls were calculated separately for the outcomes of acute coronary syndrome (ACS) events and stroke. No RCT data were available. A total of 230426 patients were included in eight observational studies and recorded as ACS events. PPV was associated with significantly lower odds of ACS events in patients 65 years and older (pooled OR=0.83 (95\% Cl 0.71 to 0.97$), \mathrm{I}^{2}=77.0 \%$ ). However, there was no significant difference in ACS events when younger people were included (pooled $\mathrm{OR}=0.86(95 \% \mathrm{Cl} 0.73$ to 1.01$\left.), \mathrm{I}^{2}=81.4 \%\right)$. Pooling of four studies, covering a total of 192210 patients, did not find a significantly reduced risk of stroke in all patients (pooled $\mathrm{OR}=1.00(95 \% \mathrm{Cl} 0.89$ to 1.12$)$, $\left.\mathrm{I}^{2}=55.3 \%\right)$, or when restricted to those 65 years and older (pooled OR=0.96 (95\% Cl 0.87 to 1.05$)$, $\mathrm{I}^{2}=22.5 \%$ ). In this meta-analysis of observational studies, the use of PPV was associated with a significantly lower risk of ACS events in the older population, but not stroke. An adequately powered and blinded RCT to confirm these findings is warranted.

\section{INTRODUCTION}

Coronary heart disease and stroke are the two leading causes of death worldwide in people aged 60 years and above, and are major contributors to the global burden of disease. ${ }^{1}$ Cholesterol, especially low-density lipoprotein (LDL), is widely believed to play a role in atherosclerotic plaque formation and subsequent cardiovascular diseases. ${ }^{23}$ Murine models have demonstrated that immunisation against oxidised LDL (oxLDL) reduces atherosclerosis. ${ }^{45}$ Interestingly, pneumococcal immunisation has been shown to elicit such anti-oxLDL antibodies in mice. ${ }^{5}$ It is therefore postulated that the pneumococcal polysaccharide vaccine (PPV), by inducing the production of anti-oxLDL antibodies, may have a protective effect on cardiovascular disease in humans. This mechanistic link is supported by a recent clinical study, which found a significant association between pneumococcal IgG and antioxLDL antibody titres. ${ }^{6}$

To date, there have been several observational studies published on the occurrence of ischaemic events post-PPV administration. Lamontagne $e t a l^{7}$ conducted a case-control study of 4995 patients and found that PPV was associated with a greater than $50 \%$ reduction in myocardial infarction. Similarly, a cohort study of 6171 participants by Eurich et $a l^{8}$ reported that PPV exposure was associated with a $60 \%$ reduction in acute coronary syndrome (ACS) events. However, large observational studies by Siriwardena et $a l^{9}(\mathrm{~N}=78706$, case-control) and Tseng et $a l^{10}(\mathrm{~N}=84170$, cohort) did not detect such benefits of the PPV. Given the conflicting results from existing observational studies, a review is warranted to resolve inconsistencies, explore heterogeneity and provide a more precise pooled estimate. We therefore set out to systematically review and meta-analyse available randomised controlled trials (RCTs) and observational studies on the PPV in preventing ischaemic cardiac events and stroke. 


\section{METHODS}

\section{Inclusion/exclusion criteria}

We included studies in human adults where PPV was the tested intervention, compared to placebo or no vaccination, and ischaemic myocardial events or ischaemic cerebrovascular events were the recorded outcomes. In contrast, studies were excluded if PPV was not the tested intervention, ischaemic events were not the recorded outcomes, did not have a comparator, or were conducted in children. Guidelines, reviews, editorial letters, conference abstracts without published data, case reports, surveys and incomplete trials were also excluded.

\section{Randomised controlled trials}

Medline, Embase and CENTRAL were searched for RCTs of PPV that either reported ischaemic events as a primary outcome or recorded these events as adverse events after vaccination, up to 30 April 2014. The search terms were adapted from the Cochrane systematic review on vaccines for preventing pneumococcal infection in adults ${ }^{11}$ and limited to RCTs in each of the databases. See online supplementary appendix 1 for a detailed search strategy.

The title and abstract were screened by two independent reviewers (SR and PM) and papers were excluded as per the exclusion criteria stated above. Shortlisted studies had their full text reviewed independently by the two reviewers (SR and $\mathrm{PM}$ ) and discrepancies were resolved by consensus. Only published results were considered for this review; study authors were not contacted for unpublished data.

\section{Observational studies}

Medline, Embase and CENTRAL were searched for observational studies on PPV and cardiovascular disease up to 30 April 2014, using search terms adapted from relevant Cochrane systematic reviews, ${ }^{11} 12$ the Cochrane Stroke Review Group and the Scottish Intercollegiate Guidelines Network (SIGN). The observational studies filter from SIGN was used. See online supplementary appendix 2 for a detailed search strategy.

The title and abstract were screened by two independent reviewers (SR and EW) and were excluded as per the exclusion criteria stated above. Shortlisted studies had their full text reviewed independently by two reviewers (SR and EW) and data extracted independently if eligible for inclusion. Reference lists and bibliographies of relevant reviews were scanned for additional studies. The data extraction form was designed a priori to capture known and possible confounders of PPV exposure and ischaemic event (eg, previous ACS or stroke, ischaemic heart disease, smoking history and diabetes) at baseline. Each study was assessed using the validated Newcastle-Ottawa Quality Assessment Scale ${ }^{13}$ for cohort studies and case-control studies. Discrepancies in both study inclusion and data extraction were resolved by consensus. Only published results were considered for this review; study authors were not contacted for unpublished data

\section{Sensitivity analyses}

Some studies reported effect sizes for subsets such as older population. Our primary analyses were restricted to people aged 65 years and above where data existed, since this population is considered to be at increased risk of morbidity and mortality from pneumococcal infection. ${ }^{14}$ Additional analyses were carried out using all available data to explore changes to the overall pooled ratio.

\section{Statistical analyses}

Data were analysed using STATA V.11 (StataCorp. 2009. Stata Statistical Software: Release 11. College Station, Texas, USA: StataCorp LP.). Random effects models were used for meta-analyses and studies were pooled according to the measured outcomes (ACS or stroke). The adjusted ORs (aOR) or HRs (aHR) from each study were weighted and combined to produce an overall pooled ratio for each outcome. $\mathrm{Q}$ statistics and $\mathrm{I}^{2}$ were calculated to examine heterogeneity. Where between-study heterogeneity existed, meta-regression was carried out to determine the source of heterogeneity. Meta-regression only used individual predictors that were available consistently across published data. Where the average age of the entire cohort was not reported, it was calculated from the age category proportions published. For probability testing, $\alpha$ was set to 0.05 . The Egger test was performed to detect study size effects (interpreted as potential publication bias ${ }^{15}$ and a contour-enhanced funnel plot was used to demonstrate this graphically.

\section{RESULTS \\ RCTs of PPV}

A total of 1041 unique results were found after removing duplicates, of which only three studies reported cardiovascular or neurological causes of death for control and vaccine groups separately during follow-up. ${ }^{16-18}$ None of these were suitable for data extraction due to uncertainty over whether these events were ischaemic in nature. Causes of death were listed simply as 'Cardiac', 'Neurologic', 'Cardiovascular', 'Cerebrovascular' and 'Central nervous' in the three studies, and there were insufficient data to tell whether these deaths were due to haemorrhagic or chronic congestive causes. See figure 1 for a flow chart of the selection process.

\section{Observational studies}

A total of 263 unique results were found after removing duplicates (see figure 2 for a flow chart of the selection process). Thirteen papers describing nine studies were included for data extraction. Four studies were casecontrol designs examining exposure to PPV in those with myocardial infarction or stroke events. ${ }^{79} 19{ }^{20}$ Five studies were cohort studies that reported on ACS events 
Figure 1. Flow diagram of the study selection process for randomised controlled trials.

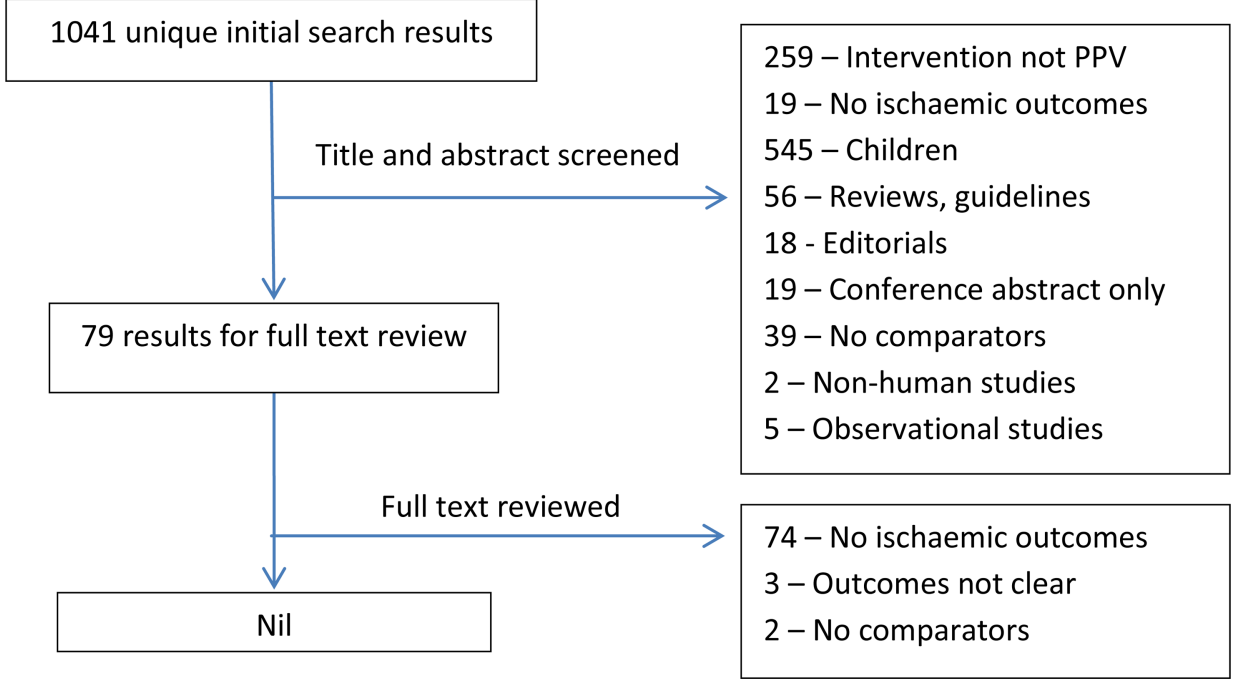

after PPV administration. ${ }^{8} 1021-23$ Three of these cohort studies also reported incidence of stroke post-PPV exposure. $^{102124} \mathrm{~A}$ summary of the studies included in this review is presented in tables 1 and 2. In general, study quality was reasonable with all studies scoring at least 6/9 on the Newcastle-Ottawa Quality Assessment Scale (see online supplementary file for a detailed assessment). Lengths of follow-up for cohort studies varied from 90 days postvaccination for primary outcome in Eurich $e t a l^{8}$ to a maximum of 6 years in other studies. It also appears that Jackson $e t a l^{22}$ only included results of PPV association with ACS as a post hoc analysis.

\section{ACS outcomes}

In the primary meta-analysis of PPV and ACS events in people aged 65 years and above (age restriction was possible in three studies), contour-enhanced funnel plots of eight studies $^{7-10} 1921-23$ did not indicate the presence of publication bias (Egger test $\mathrm{p}$ value $=0.165) . \mathrm{I}^{2}(77.0 \%)$ demonstrated significant heterogeneity between studies. A pooled ratio of 0.83 (95\% CI 0.71 to 0.97 ) was in favour of PPV (figures 3 and 4).

When age restriction was not applied (ie, younger population included from Tseng et al 2010, Eurich et al 2012 and Siriwadena et al 2010), the analysis produced a pooled ratio of 0.86 (95\% CI 0.73 to 1.01$)$. Publication bias was not detected (Egger test $\mathrm{p}$ value $=0.202$ ) while heterogeneity remained significant $\quad\left(\mathrm{I}^{2}=81.4 \%\right.$ ) (see online supplementary appendix 3).

Additional analyses were performed with pooling of studies based on design (cohort or case-control). The five cohort studies produced a pooled HR of 0.85 (95\% CI 0.68 to $1.07, \mathrm{I}^{2}=67.6 \%$ ), while the three case-control studies produced a pooled OR of 0.78 (95\% CI 0.52 to $1.16, \mathrm{I}^{2}=88.3 \%$ ) for ACS events (age restriction applied where possible) (see online supplementary appendix 4).

Meta-regressions using average age, gender, smoking status or history of diabetes mellitus as individual
Figure 2. Flow diagram of the study selection process for observational studies.

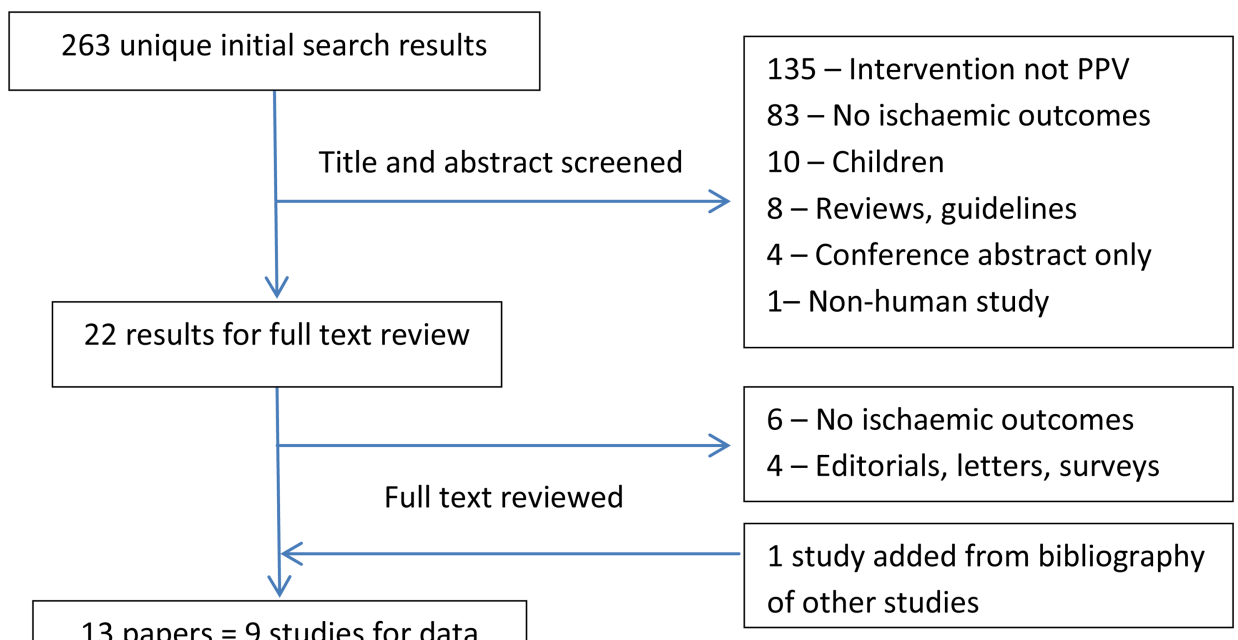


Table 1 Characteristics of studies included in the meta-analysis

\begin{tabular}{|c|c|c|c|c|c|c|c|c|c|}
\hline Authors (year) & $\begin{array}{l}\text { Jackson } \\
\text { et al (2002) }\end{array}$ & $\begin{array}{l}\text { Hung } \\
\text { et al (2010) }\end{array}$ & $\begin{array}{l}\text { Tseng } \\
\text { et al (2010) }\end{array}$ & $\begin{array}{l}\text { Eurich } \\
\text { et al (2012) }\end{array}$ & $\begin{array}{l}\text { Vila-Corcoles } \\
\text { et al (2014) } \\
\text { Ochoa-Gondar } \\
\text { et al (2014) }\end{array}$ & $\begin{array}{l}\text { Meyers } \\
\text { et al (2004) }\end{array}$ & $\begin{array}{l}\text { Lamontagne } \\
\text { et al (2008) }\end{array}$ & $\begin{array}{l}\text { Siriwardena } \\
\text { et al (2010) }\end{array}$ & $\begin{array}{l}\text { Siriwardena } \\
\text { et al (2014) }\end{array}$ \\
\hline Study type & Cohort & Cohort & Cohort & Cohort & Cohort & Case-control & Case-control & Case-control & Case-control \\
\hline Location & $\begin{array}{l}\text { Washington } \\
\text { state, USA }\end{array}$ & Hong Kong & California, USA & $\begin{array}{l}\text { Alberta, } \\
\text { Canada }\end{array}$ & Tarragona, Spain & Kansas, USA & Quebec, Canada & $\begin{array}{l}\text { England and } \\
\text { Wales }\end{array}$ & $\begin{array}{l}\text { England and } \\
\text { Wales }\end{array}$ \\
\hline Study period & $\begin{array}{l}\text { August } 1992- \\
\text { December } 1996\end{array}$ & $\begin{array}{l}03 \text { December 2007- } \\
30 \text { June } 2008\end{array}$ & $\begin{array}{l}\text { January 2002- } \\
\text { December } 2007\end{array}$ & 2000-2002 & $\begin{array}{l}\text { December 2008- } \\
\text { November } 2011\end{array}$ & $\begin{array}{l}\text { November } \\
2001-\text { March } \\
2002\end{array}$ & $\begin{array}{l}\text { January 1997- } \\
\text { December } 2003\end{array}$ & $\begin{array}{l}\text { November } 2001 \\
\text { - May } 2007\end{array}$ & $\begin{array}{l}\text { September } 2001 \\
\text {-August } 2009\end{array}$ \\
\hline Intervention & PPV & PPV & PPV & PPV & PPV & & & & \\
\hline Comparator & Unvaccinated & Unvaccinated & Unvaccinated & Unvaccinated & Unvaccinated & & & & \\
\hline $\begin{array}{l}\text { Follow-up time } \\
\text { (retrospective for case- } \\
\text { control studies) }\end{array}$ & Median 2.3 years & $\begin{array}{l}45834 \\
\text { person-years, } \\
\text { maximum } 1.2 \text { years }\end{array}$ & $\begin{array}{l}\text { Mean } 4.7 \text { years, } \\
\text { Median } 5.3 \text { years }\end{array}$ & 90 days & $\begin{array}{l}3 \text { years, } 76033 \\
\text { person-years }\end{array}$ & $\begin{array}{l}\text { Maximum } \\
5 \text { years }\end{array}$ & $\begin{array}{l}\text { Maximum } \\
10 \text { years }\end{array}$ & Not specified & Not specified \\
\hline Case & & & & & & All AMI & New AMI & New AMI & New stroke/TIA \\
\hline Control & & & & & & $\begin{array}{l}\text { New bone } \\
\text { fractures }\end{array}$ & $\begin{array}{l}\text { Surgical } \\
\text { admissions }\end{array}$ & $\begin{array}{l}\text { Random } \\
\text { matched 1:4 }\end{array}$ & $\begin{array}{l}\text { Random } \\
\text { matched 1:1 }\end{array}$ \\
\hline Total participants & 1378 & $36636^{*}$ & 84170 & 6171 & 27204 & 534 & 4995 & 78706 & $94022 \dagger$ \\
\hline Average age (years) $\ddagger$ & 64 & 75 & 58.4 & 59 & 71.7 & 69 & 58.9 & $65.6 \S$ & $65.3 \S$ \\
\hline$\%$ male & 67 & 45.3 & 100 & 52.8 & 44.6 & 52.2 & 68.5 & 38.5 & 48.0 \\
\hline \multicolumn{10}{|c|}{ Previous ischaemic events (\%) } \\
\hline Stroke & & 7.3 & 3.4 & & 4.75 & & 0 & $\begin{array}{l}6.25 \text { (stroke or } \\
\text { TIA) }\end{array}$ & 0 \\
\hline $\begin{array}{l}\text { MI } \\
\text { ACS }\end{array}$ & 100 & 1.2 & 7.2 & & & & $\begin{array}{l}0 \\
0\end{array}$ & 0 & \\
\hline Ever smoked (\%) & & 13.7 & 57.4 & 36.4 & 31.3 & 59.7 & & 26.2 & 53.4 \\
\hline History of DM (\%) & & 24.4 & 12.4 & 11.3 & 21.7 & & 7.1 & 10.3 & 10.5 \\
\hline
\end{tabular}

*27 268 participants from PPV alone and unvaccinated groups used in meta-analysis. Original study included influenza vaccine as well.

†53 568 participants from stroke only cases and matched controls used in meta-analysis, as adjusted ORs were reported separately for stroke and TIA.

†Range or SD of average age were not presented in all original publications.

$\S$ Average age not published, calculated using data available for proportions of those $40-64$ years old and $\geq 65$ years old. Average life expectancy for 2001 estimated as 80 years old using UK.

National Statistics accessed via http://www.statistics.gov.uk

ACS, acute coronary syndrome; AMI, acute myocardial infarction; DM, diabetes mellitus; PPV, pneumococcal polysaccharide vaccine; TIA, transient ischaemic attack. 


\begin{tabular}{|c|c|c|c|c|c|c|c|c|c|}
\hline Authors (year) & $\begin{array}{l}\text { Jackson } \\
\text { et al (2002) }\end{array}$ & $\begin{array}{l}\text { Hung } \\
\text { et al (2010) }\end{array}$ & $\begin{array}{l}\text { Tseng } \\
\text { et al (2010) }\end{array}$ & $\begin{array}{l}\text { Eurich } \\
\text { et al (2012) }\end{array}$ & $\begin{array}{l}\text { Vila-Corcoles } \\
\text { et al (2014) } \\
\text { Ochoa-Gondar } \\
\text { et al (2014) }\end{array}$ & $\begin{array}{l}\text { Meyers } \\
\text { et al (2004) }\end{array}$ & $\begin{array}{l}\text { Lamontagne } \\
\text { et al (2008) }\end{array}$ & $\begin{array}{l}\text { Siriwardena } \\
\text { et al (2010) }\end{array}$ & $\begin{array}{l}\text { Siriwardena } \\
\text { et al(2014) }\end{array}$ \\
\hline Study type & Cohort & Cohort & Cohort & Cohort & Cohort & $\begin{array}{l}\text { Case- } \\
\text { control }\end{array}$ & Case-control & Case-control & Case-control \\
\hline \multicolumn{10}{|l|}{ Newcastle-Ottawa quality scale } \\
\hline Selection & $3 / 4$ & $3 / 4$ & $3 / 4$ & $2 / 4$ & $3 / 4$ & $3 / 4$ & $2 / 4$ & $2 / 4$ & $3 / 4$ \\
\hline Comparability & $2 / 2$ & $0 / 2$ & $2 / 2$ & $2 / 2$ & $2 / 2$ & $1 / 2$ & $1 / 2$ & $2 / 2$ & $2 / 2$ \\
\hline $\begin{array}{l}\text { Outcome (cohort)/exposure } \\
\text { (case-control) }\end{array}$ & $3 / 3$ & $3 / 3$ & $2 / 3$ & $3 / 3$ & $3 / 3$ & $2 / 3$ & $3 / 3$ & $3 / 3$ & $3 / 3$ \\
\hline $\begin{array}{l}\text { 1st outcome recorded (cohort)/ } \\
\text { intervention exposed to (case- } \\
\text { control) }\end{array}$ & $\begin{array}{l}\text { Recurrent } \\
\text { cardiac } \\
\text { event }^{\star}\end{array}$ & AMI & AMI (age $\geq 65$ ) & $\begin{array}{l}\text { Composite ACS } \dagger \\
\text { (propensity-matched)‡ }\end{array}$ & AMI & PPV & PPV only§ & PPV (age $\geq 65$ ) & PPV (age $\geq 65$ ) \\
\hline $\begin{array}{l}\text { Number of events or event } \\
\text { rate (cohort), exposure to } \\
\text { intervention (case-control) }\end{array}$ & & $\begin{array}{l}21 / 1000 \text { p-y (PPV } \\
\text { only), } 21 / 1000 \text { p-y } \\
\text { (unvaccinated) }\end{array}$ & & $\begin{array}{l}\text { 25/724 (PPV), 54/724 } \\
\text { (unvaccinated) }\end{array}$ & $\begin{array}{l}\text { 136/8981 (PPV), } \\
223 / 18223 \\
\text { (unvaccinated) }\end{array}$ & $\begin{array}{l}107 / 335 \\
\text { (cases), } 78 / \\
199 \\
\text { (controls) }\end{array}$ & $\begin{array}{l}71 / 199 \text { (cases), } \\
465 / 3996 \\
\text { (controls) }\end{array}$ & $\begin{array}{l}5531 / 10671 \\
\text { (cases), } 20134 / \\
41335 \\
\text { (controls) }\end{array}$ & $\begin{array}{l}14835 / 20522 \\
\text { (cases), } 15394 / \\
20522 \\
\text { (controls) }\end{array}$ \\
\hline Most adjusted ratio & $\mathrm{aHR}=1.08$ & $\mathrm{aHR}=0.79$ & $\mathrm{aHR}=0.89$ & $\mathrm{aHR}=0.46$ & $\mathrm{aHR}=1.04$ & $\mathrm{aOR}=0.89$ & $\mathrm{aOR}=0.53$ & $\mathrm{aOR}=0.97$ & $\mathrm{aOR}=1.00$ \\
\hline $\begin{array}{l}95 \% \mathrm{Cl} \\
\text { 2nd outcome/intervention } \\
\text { recorded }\end{array}$ & $0.73-1.59$ & $\begin{array}{l}0.48-1.28 \\
\text { Ischaemic stroke }\end{array}$ & $\begin{array}{l}0.80-1.01 \\
\text { Stroke (age } \geq 65)\end{array}$ & $\begin{array}{l}0.28-0.73 \\
\text { Composite ACS } \dagger\end{array}$ & $\begin{array}{l}0.83-1.31 \\
\text { Ischaemic stroke }\end{array}$ & $0.60-1.33$ & $0.40-0.70$ & $\begin{array}{l}0.91-1.03 \\
\text { PPV (all ages) }\end{array}$ & $\begin{array}{l}0.94-1.05 \\
\text { PPV (all ages) }\end{array}$ \\
\hline $\begin{array}{l}\text { Number of events or event } \\
\text { rate (cohort), exposure to } \\
\text { intervention (case-control) }\end{array}$ & & $\begin{array}{l}\text { 25/1000 p-y (PPV } \\
\text { only), 36/1000 p-y } \\
\text { (unvaccinated) }\end{array}$ & & $\begin{array}{l}\text { 25/725 (PPV), 150/5446 } \\
\text { (unvaccinated) }\end{array}$ & $\begin{array}{l}\text { 133/8981 (PPV), } \\
210 / 18223 \\
\text { (unvaccinated) }\end{array}$ & & & $\begin{array}{l}6153 / 16012 \\
\text { (cases), } 21734 / \\
62694 \\
\text { (controls) }\end{array}$ & $\begin{array}{l}17206 / 26784 \\
\text { (cases), } 16773 / \\
26784 \\
\text { (controls) }\end{array}$ \\
\hline Most adjusted ratio & & $\mathrm{aHR}=0.79$ & $\mathrm{aHR}=0.85$ & $\mathrm{aHR}=0.42$ & $\mathrm{aHR}=0.97$ & & & $\mathrm{aOR}=0.98$ & $\mathrm{aOR}=0.96$ \\
\hline $95 \% \mathrm{Cl}$ & & $0.54-1.14$ & $0.70-1.03$ & $0.27-0.66$ & $0.77-1.23$ & & & $0.93-1.04$ & $0.92-1.02$ \\
\hline 3rd outcome recorded & & & AMI (all ages) & $\begin{array}{l}\text { Composite } \mathrm{ACS}^{+} \text {(age } \\
\geq 65)\end{array}$ & & & & & \\
\hline $\begin{array}{l}\text { Number of events or event } \\
\text { rate }\end{array}$ & & & $\begin{array}{l}\text { 1724/36 } 309 \\
\text { (PPV), 981/ } \\
47861 \\
\text { (unvaccinated) }\end{array}$ & & & & & & \\
\hline Most adjusted ratio & & & $\mathrm{aHR}=1.09$ & $\mathrm{aHR}=0.44$ & & & & & \\
\hline $95 \% \mathrm{Cl}$ & & & $0.98-1.21$ & $0.28-0.69$ & & & & & \\
\hline 4th outcome recorded & & & Stroke (all ages) & & & & & & \\
\hline $\begin{array}{l}\text { Number of events or event } \\
\text { rate }\end{array}$ & & & $\begin{array}{l}799 / 36309 \\
\text { (PPV), 335/ } \\
47861 \\
\text { (unvaccinated) }\end{array}$ & & & & & & \\
\hline Most adjusted ratio & & & $\mathrm{aHR}=1.14$ & & & & & & \\
\hline $95 \% \mathrm{Cl}$ & & & $1.00-1.31$ & & & & & & \\
\hline
\end{tabular}

${ }^{*}$ Composite of non-fatal MI and atherosclerotic cardiovascular disease death, including MI, IHD, CHF, hypertensive heart disease, cardiac arrest and AF.

tIncluding myocardial infarction or unstable angina or death attributed to ACS.

¥The propensity-matched analysis (c-statistic=0.86) permitted 724 of the $725(99.9 \%)$ patients exposed to PPV to be matched to 724 controls. Propensity (to receive PPV) score analysis was based on variables present before pneumonia onset that could be associated with the decision to administer PPV.

$\S$ Original study also included influenza vaccination as another intervention.

ACS, acute coronary syndrome; AF, atrial fibrillation; aHR, adjusted HR; AMI, acute myocardial infarction; aOR, adjusted OR; CHF, congestive heart failure; IHD, ischaemic heart disease; MI, myocardial infarction; PPV, pneumococcal polysaccharide vaccine; $p$ - $y$, person-years. 
Figure 3. Forest plots of primary analysis of pneumococcal polysaccharide vaccine (PPV) and acute coronary syndrome events (upper), PPV and stroke (lower), age restricted to $\geq 65$ years where possible.

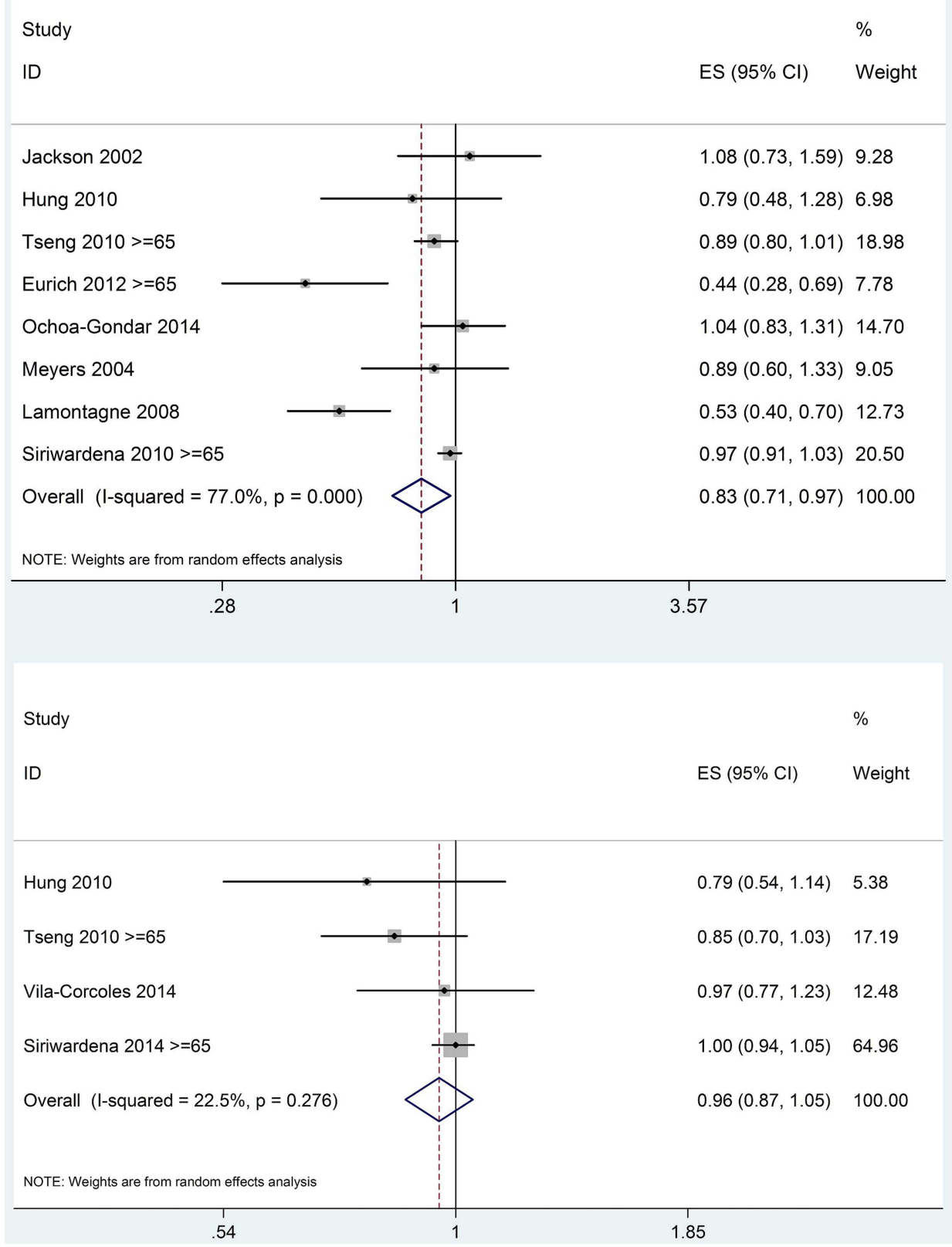

predictors of aOR or aHR did not identify any source of between-study heterogeneity (see online supplementary appendix 5).

\section{Stroke outcomes}

Separate analysis of the three cohort studies and the one case-control study on PPV and stroke risk, ${ }^{10202124}$ and restricting age to 65 years and above in two of the studies for primary meta-analysis, produced a pooled ratio of 0.96 (95\% CI 0.0 .87 to 1.05$)$. $\mathrm{I}^{2}(22.5 \%)$ did not indicate significant heterogeneity. A contour-enhanced funnel plot and Egger test $p$ value $=0.151$ did not indicate any publication bias, although with so few studies such bias would be difficult to detect (figures 2 and 3 ).

Meta-analysis without age restriction in these four studies produced a similar pooled ratio of 1.00 (95\% CI
0.89 to 1.12$)$, with $\mathrm{I}^{2}(55.3 \%)$ suggesting some degree of heterogeneity (see online supplementary appendix 3 ).

Additional analysis was performed with the pooling of cohort studies. The three cohort studies produced a pooled HR of 0.88 (95\% CI 0.77 to $\left.1.01, \mathrm{I}^{2}=0.0 \%\right)$ for stroke outcomes (age restriction applied where possible) (see online supplementary appendix 4).

Meta-regression was not carried out due to a lack of sufficient studies.

\section{DISCUSSION}

In this meta-analysis of 230426 patients from eight observational studies, PPV was associated with significantly lower odds of ACS in the population aged 65 years and above. PPV was not associated with a lower risk of stroke from meta-analysis of four observational 
Figure 4. Contour-enhanced funnel plots of studies included in the primary analysis of pneumococcal polysaccharide vaccine (PPV) and acute coronary syndrome events (upper), PPV and stroke (lower).
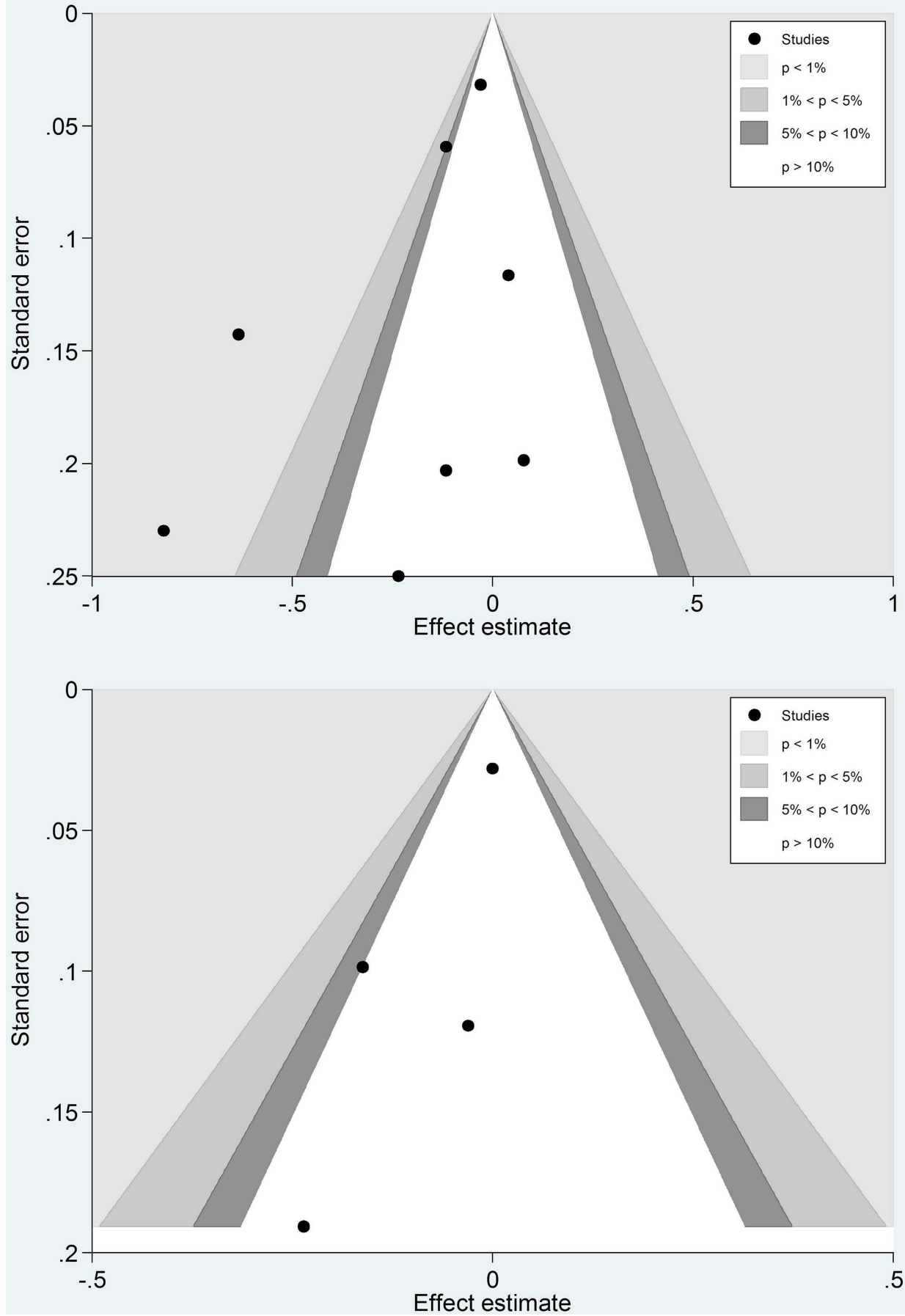

studies consisting of 192210 patients. This is the first published systematic review on this topic, to the best of the authors' knowledge, and provides further impetus for the need for a large RCT on this important topic.

To date, there have been no known RCTs examining cardiovascular protective effects of PPV. This systematic review did not identify any RCTs of the PPV that reported ischaemic events either as primary end points or as adverse events in sufficient detail to be included. Most of the recorded adverse events after PPV administration were local injection site reactions and systemic reactions such as fever and fatigue. The majority of these studies only had follow-up of hours to days
post-PPV administration, which was too short to observe the development of ischaemic events. Several RCTs mentioned cardiovascular complications during follow-up, but failed to specify whether these were in control or vaccinated groups. ${ }^{25-27}$ The three studies considered for data extraction ${ }^{16-18}$ used broad terms such as 'cardiovascular disease', 'cardiac', 'central nervous', and 'neurologic' to describe the causes of death in their patients; hence, we could not be certain they were ischaemic in nature. The overall numbers of events were also low, totalling 178 across all three RCTs, 166 of which were from one study. They were therefore excluded from further data extraction and analysis. 
This review supports the postulated atherosclerotic protective effect of PPV in preventing ACS events, in the elderly population. We found that administration of PPV is associated with an approximately $17 \%$ relative reduction in the odds of ACS in people aged 65 years and above. Although the point estimate remained similar, this benefit lost statistical significance when a younger population was included, most likely due to the lower event rate and hence decreased power. An association between PPV and stroke risk was not observed regardless of age restriction; this may be due to the lower incidence of stroke compared with ACS and with the lower number of studies. In addition, stroke risk may be contaminated by haemorrhagic stroke instead of ischaemic stroke, or stroke mimics in some of the older studies without MRI confirmation. This would lead to a greater misclassification of stroke compared with ACS, which would reduce power.

Past research has consistently shown that vaccination with Streptococcus pneumonia leads to a reduction of atherosclerosis in mice. ${ }^{4} 5$ It appears that phosphorylcholine lipid antigens expressed on the cell wall polysaccharide of $S$. pneumonia induce the production of antibodies that cross-react with oxLDL, a component of atherosclerotic plaques. There are three possible mechanisms by which these antibodies may have a cardioprotective effect ${ }^{28}$

1. The antibodies bind oxLDL and may prevent their uptake by macrophages, thereby blocking the formation of foam cells in plaques.

2. The antibodies may bind to oxLDL on apoptotic cells in the plaque and help clear them.

3. The antibodies may neutralise the proinflammatory cascade in plaques induced by oxLDL.

Similar mechanisms may also occur in humans, leading to the possibility that pneumococcal vaccination protects against atherosclerosis, which would be consistent with our findings.

A large proportion of the literature search results classified as 'intervention irrelevant' were studies of the pneumococcal protein conjugate vaccine (PCV), tested in children or immunocompromised adults. However, the PCV has altered structure and antigenicity compared with the PPV, and hence is not thought to trigger the formation of the protective antibodies against oxLDL.

A recent meta-analysis of six RCTs involving 6735 patients, with a mean follow-up time of 7.9 months, demonstrated that influenza vaccination was associated with a significantly lower risk of major adverse cardiovascular events (risk ratio $=0.64,95 \%$ CI 0.48 to 0.86 ).$^{29}$ It has been suggested that the reduced short-term risk of cardiovascular events offered by this vaccination is due to a reduction in infection, which can be a trigger in the inflammatory cascade that leads to the progression of atherosclerosis. ${ }^{7}$ The protective effect of influenza vaccinate seems to wane by $9-12$ months. In contrast, most of the studies in this review demonstrated a protective association of PPV over several years, suggesting a different mechanism that takes longer to develop, consistent with the proposed anti-oxLDL pathway.

The absence of RCT data in the review means the meta-analysis was solely based on observational data and prone to many biases, confounders and design inconsistencies. We have used the most adjusted summary statistics from each study in the meta-analysis in an attempt to minimise their impact, but residual confounding may nevertheless still be present. Risk of a 'healthy user effect' in observational studies, that is, that those who obtain the vaccine are healthier than those who do not, could bias results away from the null. However, demographics of the immunised group across virtually all studies indicated more comorbidity than that of the non-immunised group, which would bias towards more cardiovascular events rather than less in the immunised group, that is, in this case, residual confounding would most likely bias towards the null.

Major limitations of this meta-analysis included significant heterogeneity between studies and varying quality of individual observational studies. The follow-up time varied from 90 days to several years among the studies. Baseline data varied widely not only in magnitude but also in quality for average age, gender distribution, history of ischaemic events and risk factors. Meta-regression was restricted by these poorly defined baseline data, some of which were missing in some studies, limiting its usefulness in the exploration of between-study heterogeneity. ORs from retrospective case-control studies were combined with HRs from prospective cohort studies to produce an estimate of true relative risk. Types of ischaemic events recorded ranged from broad spectrum cardiac events to specifically AMIs only. Tseng et $a l$ s definition of stroke cases included "acute, but illdefined cerebrovascular diseases (ICD-9 code 436.xx)" and "deaths caused by stroke, not specified as haemorrhage or infarction (ICD-10 code I64)", and therefore may have misclassified some non-ischaemic strokes as outcome. This 'noise' in classification of outcomes would be expected to reduce power but not cause bias, as long as it is not differential between vaccinated and unvaccinated groups.

It is also noted that the inclusion of young (less than 65 years old) participants removed any protective effect; we believe this is most likely due to the low event rate in this group and hence the 'dilution' of the pooled OR seen with older patients. Only Tseng et al, Eurich et al and Siriwardena et al reported outcomes for the subgroups aged 65 years and above, probably because a large proportion of their study participants were younger, healthier and would have been less likely to benefit from PPV. Other studies with an average age less than 65 (Jackson et al and Lamontagne et al) did not perform separate analyses for their older, more disease susceptible groups. This rendered their results less applicable to the clinical population, where the pneumococcal vaccine is recommended for the elderly and those more prone to pneumococcal infections. ${ }^{14}$ 
From the trends observed in the age restricted analyses, the pooled estimate would probably favour PPV had all studies reported outcomes consistently across age groups.

We suggest that the results of this review on the cardiovascular protective effect of PPV be treated with cautious optimism. Despite many limitations in methodology due to the different qualities of individual studies, the pooled effect favours PPV intervention for the elderly, especially since there is a strong possibility of confounding that would bias against the vaccine because vaccinated groups consistently showed greater comorbidity than nonvaccinated groups. Given the prevalence of heart attack and stroke, even a small protective effect of PPV would offer significant health benefits. An RCT investigating the effects of PPV on ischaemic events as the primary outcome is needed to prove causality. Indeed, such an RCT has been funded and is in the planning stages; we estimate that recruitment will require 6000 participants aged 55-60 years with at least two risk factors for CVD, randomised 1:1 with active or placebo vaccine and followed for at least 5 years to detect this protective effect with $80 \%$ power at a significance level of $\mathrm{p}=0.05$.

Contributors SR, DN, SCL and JA were involved in the study design. SR, EW and PM were involved in the study selection and data extraction. SR was responsible for the data analysis and writing of drafts. AH edited and rewrote subsequent versions of the manuscript. All authors proofread and contributed to the final version of the manuscript for submission. SR, DN and JA contributed to the revision of the manuscript after feedback from reviewers.

Competing interests None declared.

Provenance and peer review Not commissioned; externally peer reviewed.

Data sharing statement No additional data are available.

Open Access This is an Open Access article distributed in accordance with the Creative Commons Attribution Non Commercial (CC BY-NC 4.0) license, which permits others to distribute, remix, adapt, build upon this work noncommercially, and license their derivative works on different terms, provided the original work is properly cited and the use is non-commercial. See: http:// creativecommons.org/licenses/by-nc/4.0/

\section{REFERENCES}

1. Mackay J, Mensah GA, World Health Organization, Center for Disease Control, Myriad Editions Limited. The Atlas of Heart Disease and Stroke. Geneva: World Health Organization, 2004.

2. Libby P. Inflammation in atherosclerosis. Nature 2002;420:868-74.

3. Lusis AJ. Atherosclerosis. Nature 2000;407:233-41.

4. Caligiuri G, Khallou-Laschet J, Vandaele M, et al. Phosphorylcholine-targeting immunization reduces atherosclerosis. J Am Coll Cardiol 2007;50:540-6.

5. Binder CJ, Horkko S, Dewan A, et al. Pneumococcal vaccination decreases atherosclerotic lesion formation: molecular mimicry between Streptococcus pneumoniae and oxidized LDL. Nat Med 2003;9:736-43.

6. Suthers B, Hansbro P, Thambar S, et al. Pneumococcal vaccination may induce anti-oxidized low-density lipoprotein antibodies that have potentially protective effects against cardiovascular disease. Vaccine 2012;30:3983-5.

7. Lamontagne F, Garant MP, Carvalho JC, et al. Pneumococcal vaccination and risk of myocardial infarction. CMAJ 2008;179:773-7.

8. Eurich DT, Johnstone JJ, Minhas-Sandhu JK, et al. Pneumococcal vaccination and risk of acute coronary syndromes in patients with pneumonia: population-based cohort study. Heart 2012;98:1072-7.

9. Siriwardena AN, Gwini SM, Coupland CA. Influenza vaccination, pneumococcal vaccination and risk of acute myocardial infarction: matched case-control study. CMAJ 2010;182:1617-23.

10. Tseng HF, Slezak JM, Quinn VP, et al. Pneumococcal vaccination and risk of acute myocardial infarction and stroke in men. JAMA 2010;303:1699-706.

11. Moberley SA, Holden J, Tatham DP, et al. Vaccines for preventing pneumococcal infection in adults. Cochrane Database Syst Rev 2008;(1):CD000422.

12. Keller T, Weeda VB, van Dongen CJ, et al. Influenza vaccines for preventing coronary heart disease. Cochrane Database Syst Rev 2008;(3):CD005050.

13. Deeks JJ, Dinnes J, D'Amico R, et al. Evaluating non-randomised intervention studies. Health Technol Assess 2003;7:iii-x, 1-173.

14. [No authors listed]. Pneumococcal vaccines WHO position paper -2012. Wkly Epidemiol Rec 2012;87:129-44.

15. Peters JL, Sutton AJ, Jones DR, et al. Comparison of two methods to detect publication bias in meta-analysis. JAMA 2006;295:676-80.

16. Davis AL, Aranda CP, Schiffman G, et al. Pneumococcal infection and immunologic response to pneumococcal vaccine in chronic obstructive pulmonary disease. A pilot study. Chest 1987;92:204-12.

17. Riley ID, Tarr PI, Andrews M, et al. Immunisation with a polyvalent pneumococcal vaccine. Reduction of adult respiratory mortality in a New Guinea Highlands community. Lancet 1977;1:1338-41.

18. Simberkoff MS, Cross AP, Al-lbrahim M, et al. Efficacy of pneumococcal vaccine in high-risk patients. Results of a Veterans Administration Cooperative Study. N Engl J Med 1986;315:1318-27.

19. Meyers DG, Beahm DD, Jurisich PD, et al. Influenza and pneumococcal vaccinations fail to prevent myocardial infarction. HeartDrug 2004;4:96-100.

20. Siriwardena AN, Asghar Z, Coupland CC. Influenza and pneumococcal vaccination and risk of stroke or transient ischaemic attack-matched case control study. Vaccine 2014;32:1354-61.

21. Hung IF, Leung AY, Chu DW, et al. Prevention of acute myocardial infarction and stroke among elderly persons by dual pneumococcal and influenza vaccination: a prospective cohort study. Clin Infect Dis 2010;51:1007-16.

22. Jackson LA, Yu O, Heckbert SR, et al. Influenza vaccination is not associated with a reduction in the risk of recurrent coronary events. Am J Epidemiol 2002;156:634-40.

23. Ochoa-Gondar O, Vila-Corcoles A, Rodriguez-Blanco T, et al. Evaluating the clinical effectiveness of pneumococcal vaccination in preventing myocardial infarction: The CAPAMIS study, three-year follow-up. Vaccine 2014;32:252-7.

24. Vila-Corcoles A, Ochoa-Gondar O, Rodriguez-Blanco T, et al. Evaluating Clinical Effectiveness of Pneumococcal Vaccination in Preventing Stroke: The CAPAMIS Study, 3-Year Follow-up. J Stroke Cerebrovasc Dis 2014;23:1577-84.

25. Alfageme I, Vazquez R, Reyes N, et al. Clinical efficacy of antipneumococcal vaccination in patients with COPD. Thorax 2006;61:189-95.

26. Leech JA, Gervais A, Ruben FL. Efficacy of pneumococcal vaccine in severe chronic obstructive pulmonary disease. CMAJ 1987;136:361-5.

27. Maruyama T, Taguchi O, Niederman MS, et al. Efficacy of 23-valent pneumococcal vaccine in preventing pneumonia and improving survival in nursing home residents: double blind, randomised and placebo controlled trial. BMJ 2010;340:c1004.

28. Tsiantoulas D, Diehl CJ, Witztum JL, et al. B cells and humoral immunity in atherosclerosis. Circ Res 2014;114:1743-56.

29. Udell JA, Zawi R, Bhatt DL, et al. Association between influenza vaccination and cardiovascular outcomes in high-risk patients: a meta-analysis. JAMA 2013;310:1711-20. 